\title{
Sosialisasi Kawasan Keselamatan Operasi Penerbangan (KKOP)
}

\author{
Budi Prasetyo $^{1}$, Taufik Rohman ${ }^{2}$, Solihin $^{3}$, Sundoro ${ }^{4}$, Nawang Kalbuana ${ }^{5}$ \\ 1,2,3,4,5,6 Politeknik Penerbangan Indonesia Curug \\ e-mail: 'budi.prasetyo@ppicurug.ac.id, ${ }^{2}$ taufik.rohman@ppicurug.ac.id, ${ }^{3}$ solihin @ ppicurug.ac.id, \\ ${ }^{4}$ sundoro@ppicurug.ac.id, ${ }^{5}$ nawang.kalbuana@ppicurug.ac.id
}

\begin{abstract}
Abstrak
Sebagai salah satu peranan perguruan tinggi dalam mewujudkan Tridharma Perguruan Tinggi khususnya dibidang Penerbangan, Politeknik Penerbangan Indonesia dipandang perlu melakukan sosialisasi terkait Kawasan Keselamatan Operasi Penerbangan (KKOP) khususnya untuk masyarakat disekitar kawasan Bandar Udara. Pengabdian kepada masyarakat ini bertujuan untuk memberikan pengetahuan khususnya informasi tentang dunia penerbangan terkait dengan KKOP yang merupakan wilayah daratan dan/atau perairan dan ruang udara di sekitar bandar udara yang dipergunakan untuk kegiatan operasi penerbangan dalam rangka menjamin keselamatan penerbangan. Kegiatan ini dilaksanakan dengan metode sosialisasi kepada masyarakat sekitar Bandar Udara Budiarto dan Kawasan kampus Politeknik Penerbangan Indonesia Curug dengan melibatkan tokoh masyarakat dan pemuda pada Desa Kemuning, Kecamatan Legok, Kabupaten Tangerang, Provinsi Banten selama satu hari. Pelaksanaan sosialisasi juga melibatkan Taruna Program Studi Diploma III Operasi Bandar Udara yang secara aktif menyiapkan materi didampingi para dosen dengan harapan Taruna dapat secara langsung berinteraksi dengan masyarakat sekitar di dalam menyampaikan ilmu yang telah dipelajari di kampus. Dengan adanya kegiatan Sosialisasi KKOP ini diharapkan penyebaran pengetahuan terkait KKOP di warga Desa Kemuning diharapkan mampu meningkatkan kewaspadaan masyarakat sekitar Bandar Udara Budiarto dan kampus Politeknik Penerbangan Indonesia Curug ketika beraktifitas di sekitar kawasan operasi penerbangan.
\end{abstract}

Kata Kunci : Bandar Udara, KKOP, Keselamatan Penerbangan, Kewaspadaan, sosialiasi.

\begin{abstract}
As one of the roles of universities, especially in the field of Aviation, The Indonesian Aviation Polytechnic is considered necessary to conduct socialization related to the Aviation Operations Safety Zone (KKOP) especially for the community around the airport area. This community service aims to provide knowledge, especially information about the world of aviation related to KKOP which is a land area and / or waters and air space around the airport used for aviation operations in order to ensure flight safety. This activity was carried out by socialization method to the community around Budiarto Airport and The Campus area of Politeknik Penerbangan Indonesia Curug by involving community leaders and youth in Kemuning Village, Legok District, Tangerang Regency, Banten Province for one day. The implementation of socialization also involves Cadets Diploma III Study Program Airport Operations who actively prepare materials accompanied by lecturers in the hope that Cadets can directly interact with the surrounding community in conveying the knowledge that has been learned on campus. With this KKOP Socialization activity, it is expected that the dissemination of knowledge related to KKOP in kemuning villagers is expected to increase the awareness of the community around Budiarto Airport and the Campus of The Indonesian Aviation Polytechnic Curug when conducting activities around the aviation operations area
\end{abstract}

Keywords : Airport, KKOP, Aviation Safety, Vigilance, socialization.

\section{Pendahuluan}

Berdarkan undang-undang No 1 Tahun 2009 Kawasan Keselamatan Operasi Penerbangan (KKOP) merupakan wilayah daratan dan/atau perairan dan ruang udara di sekitar 
bandar udara yang dipergunakan untuk kegiatan operasi penerbangan dalam rangka menjamin keselamatan penerbangan. Beberapa dampak tidak diketahuinya KKOP oleh masyarakat sekitar menyebabkan naiknya tingkat kewaspadaan terhadap keselamatan penerbangan. Sehingga hal tersebut perlu disosialisasikan kepada masyarakat disekitar Kawasan bandar udara. Politeknik Penerbangan Indonesia Curug, melalui program Pengabdian Kepada Masyarakat memandang perlu untuk dilakukannya Sosialisasi terkait dengan KKOP ( Purwanto et al. 2017; Purwanto and Ritzkal 2018; R. L., Subiyanto, and Nugraha 2014; Hasuna et al. 2020; Kalbuana et al. 2020; Kalbuana and Kurnianto 2011; Lamtiar et al. 2020, 2021).

Pentingnya Kawasan Keselamatan Operasi Penerbangan (KKOP) untuk diketahui oleh masyarakat disekitar bandara sudah mulai digalakkan dilakukan penelitian (Andius Dasa Putra; Aleksander Purba 2009; Dampak Pembang. Apartemen Paltrow City Berdasarkan Persepsi Masy. Kelurahan Pedalangan, Banyumanik 2016; Mayhendra and Rohmadiani 2016; Purwadio, Ariastita, and Sulistyarso 2017; Kurnianto and Kalbuana 2011; Sugeng Budi Susilo, Alimah, and Mellawati 2017; Susanti, Nugraha, and Yuwono 2015; Winaya and A.L.W 2016; Zahra, Ahyudanari, and Istiar 2017).

Tujuan dari kegiatan Pengabdian Kepada masyarakat tentang sosialisasi Kawasan Keselamatan Operasi Penerbangan (KKOP) ini, diharapkan peserta mengetahui bahwa keselamatan adalah prioritas utama dan harus disediakan dalam setiap aktivitas penerbangan. Pengabdian kepada Masyarakat adalah kegiatan civitas akademika yang memanfaatkan ilmu pengetahuan dan teknologi untuk memajukan kesejahteraan masyarakat dan mencerdaskan kehidupan bangsa. Pelaksanaan kegiatan pengabdian masyarakat ini diharapkan:

a. Memberikan pengetahuan kepada masyarakat di sekitar Bandar Udara Budiarto dan kampus Politeknik Penerbangan Indonesia Curug mengenai Kawasan Keselamatan Operasi Penerbangan.

b. Menumbuhkan kesadaran masyarakat akan pentingnya mengutamakan keselamatan dan kewaspadaan ketika berkatifitas di sekitar area operasi penerbangan.

\section{Metode}

Ketidaktahuan warga dan masuk ke sekitar bandara dapat menyebabkan naiknya tingkat kewaspadaan terhadap keselamatan penerbangan, beberapa kasus yang ada disekitar wilayah bandara seperti pembobolan pagar kawat untuk mencari rumput, bertanam dan sampai pada pencurian besi-besi pagar sebagai parimeter. Bahkan sempat terjadi kasus yang sempat menggegerkan dunia penerbangan dimana salah seorang warga Desa Kemuning memasuki daerah runway dengan mengendarai speda motor saat kegiatan Latihan terbang berlangsung, sehingga terjadi accident yang menimbulkan kerugian harta dan nyawa, dan masih banyak kasus lain yang melatar belakangi pentingnya sosialisasi tentang Kawasan Keselamatan Penerbangan (KKOP) yang telah kami laksanakan. Dari beberapa kasus tersebut menunjukan bahwa sistem pengamanan bandar udara harus terus ditingkatkan.

Lokasi kegiatan sosialisasi berada didaerah Kawasan Keselamatan Operasi Penerbangan (KKOP) Bandar Udara Budiarto Curug, di Desa Kemuning, Kecamatan Legok, Kabupaten Tangerang, Banten. Daerah ini dipandang perlu dilakukan sosialisasi karena berbatasan langsung dengan parimeter Bandar Udara Budiarto Curug bahkan dibagian wilayah sebelah barat desa Kemuning berada diujung runway sebelah timur yang merupakan Kawasan aman, dibanding dengan jalur utara selatan yang dimungkinkan sebagai jalur crossing dengan bandara Budiarto terutama pesawat non latih.

Metode yang digunakan adalah berbentuk penyuluhan/sosialisasi dengan mempertimbangkan latar belakang peserta sosialisasi. Penjelasan diberikan dalam bentuk teks dan gambar serta video sehingga mudah dipahami. Studi kasus dijelaskan sesuai dengan 
kejadian yang terjadi, antara lain kasus drone yang menabrak sayap pesawat terbang, burung yang masuk ke dalam pesawat terbang, hewan ternak yang masuk ke dalam area bandar udara, masyarakat yang menyeberang landasan pacu, balon udara dan layang-layang, lampion, serta gunung di area bandar udara. Penjelasan diberikan oleh Dosen sehingga masyarakat yang hadir dengan berbagai usia dapat memahami dengan baik maksud dan tujuan serta materi sosialisasi. Setelah penjelasan materi kemudian dilanjutkan dengan sesi tanya jawab untuk memperdalam pemahaman masyarakat mengenai materi KKOP tersebut.

Setelah kegiatan sosialisasi berakhir diharapkan mampu menumbuhkan kesadaran di masyarakat akan pentingnya mengutamakan keselamatan dan kewaspadaan ketika beraktifitas di sekitar area operasi penerbangan Bandar Udara budiarto khususnya masyarakat Desa Kemuning, Kecamatan Legok, Kabupaten Tangerang, Banten. Materi yang disampaiakan pada kegiatan sosialisasi ini disajikan pada tabel materi sosialisasi berikut:

Tabel 1. Materi Sosialisasi

\begin{tabular}{|l|l|}
\hline No & \multicolumn{1}{|c|}{ Materi } \\
\hline 1. & Istilah dan Definisi \\
\hline 2. & Persyaratan Kawasan Keselamatan Operasi Penerbangan \\
\hline 3. & Perimeter dan Obstacle \\
\hline 4. & Studi Kasus \\
\hline 5. & Sanksi dan denda \\
\hline
\end{tabular}

\section{Hasil dan Pembahasan}

Hasil dari kegiatan pengabdian kepada masyarakat ini adalah peserta mengikuti kegiatan dengan antusias dan memberikan pertanyaan-pertanyaan mengenai kejadian-kejadian yang pernah terjadi di lingkungan bandar udara sesuai dengan pengalaman mereka. Pembahasan materi meliputi:

\section{Istilah/Definisi}

Masyarakat desa kemuning sudah diperkanalkan dengan aturan/regulasi,serta beberapa istilah yang ada dalam dunia penerbangan yang masih terkait dengan KKOP. ICAO adalah salah satu badan PBB tersebut yang diprakarsai oleh chicago convention pada tahun 1944 dan mengkususkan kegiatannya pada bidang penerbangan singkatan icao adalah internasional civil aviation organization. Drone adalah Pesawat Udara Tanpa Awak adalah sebuah mesin terbang yang berfungsi dengan kendali jarak jauh oleh penerbang (pilot) atau mampu mengendalikan dirinya sendiri dengan menggunakan hukum aerodinamika. Bird Strike atau bird hazard Bird strike atau bird hazard : adalah setiap gangguan burung etiap gangguan burung baik secara berkelompok berkelompok maupun tunggal tunggal terhadap terhadap pesawat pesawat terbang terbang pada saat proses penerbangan proses penerbangan. Lampion atau Balon Udara adalah benda yang lebih ringan dari pesawat udara yang tidak digerakkan oleh mesin, namun dapat terbang karena diisi dengan gas yang dapat mengapung (gas buoyancy) atau melalui pemanasan udara (airbome heater). Kawasan Keselamatan Operasi Penerbangan (KKOP) adalah wilayah daratan dan/atau perairan dan ruang udara di sekitar bandar udara yang dipergunakan untuk kegiatan operasi penerbangan dalam rangka menjamin keselamatan penerbangan. Kawasan pendekatan dan lepas landas adalah suatu Kawasan perpanjangan kedua ujung landas pacu, di bawah lintasan pesawat udara setelah lepas landas atau akan mendarat, yang dibatasi oleh ukuran Panjang dan lebar tertentu. Kawasan kemungkinan bahaya kecelakaan adalah Sebagian dari Kawasan pendekatan yang berbatasan langsung dengan ujung-ujung landas pacu dan mempunyai ukuran tertentu, yang dapat menimbulkan kemungkinan terjadinya kecelakaan. 
Kawasan di bawah permukaan horizontal dalam adalah bidang datar di atas dan di sekitar bandar udara yang dibatasi oleh radius dan ketinggian dengan ukuran tertentu untuk kepentingan pesawat udara melakukan terbang rendah pada waktu akan mendarat atau setelah lepas landas. Kawasan di bawah permukaan horizontal luar adalah bidang datar di sekitar bandar udara yang dibatasi oleh radius dan ketinggian dengan ukuran tertentu untuk kepentingan keselamatan dan efisiensi operasi penerbangan antara lain pada waktu pesawat melakukan pendekatan untuk mendarat dan Gerakan setelah tinggal landas atau Gerakan dalam hal mengalami kegagalan dalam pendaratan. Kawasan di bawah permukaan kerucut adalah bidang dari suatu kerucut yang bagian bawahnya dibatasi oleh garis perpotongan dengan horizontal dalam dan bagian atasnya dibatasi oleh garis perpotongan dengan permukaan horizontal luar, masingmasing dengan radius dan ketinggian tertentu dihitung dari titik referensi yang ditentukan. Kawasan di bawah permukaan transisi adalah bidang dengan kemiringan tertentu sejajar dengan dan berjarak tertentu dari sumbu landas pacu, pada bagian bawah dibatasi oleh titik perpotongan dengan garis-garis datar yang ditarik tegak lurus pada sumbu landas pacu dan pada bagian atas dibatasi oleh garis perpotongan dengan permukaan horizontal dalam. Permukaan Utama adalah permukaan yang garis tengahnya berhimpit dengan sumbu landas pacu yang membentang sampai Panjang tertentu di luar setiap ujung landas pacu dan lebar tertentu, dengan ketinggian untuk setiap titik pada permukaan utama diperhitungkan sama dengan ketinggian titik terdekat pada sumbu landas pacu. Kawasan di sekitar penempatan alat bantu navigasi penerbangan adalah Kawasan di skeitar penempatan alat bantu navigasi penerbangan di dalam dan/atau di luar daerah lingkungan kerja, yang penggunaannya harus memenuhi persyaratan tertentu guna menjamin kinerja/efisiensi alat bantu navigasi penerbangan dan keselamatan penerbangan. Permukaan kerucut pada alat bantu navigasi penerbangan adalah permukaan kerucut pada alat bantu navigasi penerbangan adalah Kawasan di atas permukaan garis sudut yang dibatasi oleh garis jarak dengan radius dan ketinggian tertentu dihitung dari titik referensi yang ditentukan pada peralatan masing-masing. Elevasi dasar pada alat bantu navigasi penerbangan adalah ketinggian dasar suatu titik atau Kawasan terhadap permukaan laut rata-rata (Mean Sea Level /MSL). Titik acu Kawasan bandar udara (Aerodorme Reference Point/ARP) adalah titik koordinat bandar udara yang menunjukkan posisi bandar udara terhadap koordinat geografis. Landas pacu adalah suatu daerah persegi Panjang yang ditentukan pada bandar udara di daratan atau perairan yang dipergunakan untuk pendaratan dan lepas landas pesawat udara.

\section{Persyaratan Kawasan Keselamatan Operasi Penerbangan.}

Dalam pembuatan kawasan keselamatan operasi penerbangan di bandar udara dan sekitarnya diperlukan data sebagai berikut:

a. Rencana induk bandar udara atau rencana pengembangan bandar udara;

b. Rencana pengembangan wilayah dan pengembangan kota jangka panjang untuk lokasi yang bersangkutan;

c. Rencana prosedur dan pengaturan lalu lintas udara;

d. Peta topografi;

e. Titik kerangka dasar nasional.

\section{Perimeter dan Obstacle}

Perimeter adalah batas luar lingkaran dari tempat tertutup atau tempat terlindungi (bandar udara, kantor kedutaan, dsb). Tinggi minimal 2,44 meter. Kawat berduri di atasnya. Pemberian teralis pada drainase atau saluran pembuangan. Diberi penerangan pada titik tertentu atau 
tempat-tempat yang dapat diduga rawan penyusupan. Tersedianya jalan inspeksi dan dilengkapi dengan pintu darurat.

Obstacle bergerak adalag obyek bergerak/dinamis yang dapat mengganggu jalannya penerbangan. Obstacle tidak bergerak adalah obyek diam/statis yang dapat mengganggu jalannya penerbangan. Halangan/obstacle merupakan hal sensitif dalam penerbangan dikarenakan dapat mengganggu penerbangan sebagaimana dapat menabrak pesawat yang sedang terbang terutama pada saat approaching dan take off.

\section{Studi kasus}

Studi kasus dijelaskan sesuai dengan kejadian yang terjadi, antara lain kasus Penerobos Pagar, Drone, birdstrike, balon udara, layang-layang, lampion, menara BTS, dan Laser pointer. Drone yang menabrak sayap pesawat terbang, burung yang masuk ke dalam pesawat terbang, hewan ternak yang masuk ke dalam area bandar udara, masyarakat yang menyeberang landasan pacu, balon udara dan layang-layang, lampion, serta gunung di area bandar udara. Penjelasan diberikan oleh Dosen sehingga masyarakat yang hadir dengan berbagai usia dapat memahami dengan baik maksud dan tujuan serta materi sosialisasi. Setelah penjelasan materi kemudian dilanjutkan dengan sesi tanya jawab untuk memperdalam pemahaman masyarakat mengenai materi KKOP tersebut.

\section{Sanksi dan Denda}

UU no. 1 Tahun 2009 Pasal 210: setiap orang dilarang berada di daerah tertentu di bandar udara, membuat halangan (obstacle), dan/atau melakukan kegiatan lain di kawasan keselamatan operasi penerbangan yang dapat membahayakan keselamatan dan keamanan penerbangan, kecuali memperoleh izin dari otoritas bandar udara. UU no:1 Tahun 2009 Pasal 421 Ayat (1) Setiap orang berada di daerah tertentu di bandar udara, tanpa memperoleh izin dari otoritas bandar udarasebagaimana dimaksud dalam Pasal 210 dipidana denganpidana penjara paling lama 1 (satu) tahun atau denda paling banyak Rp100.000.000,00 (seratus juta rupiah).

\section{Dokumentasi Kegiatan Sosialisasi}

Berikut dokumentasi kegiatan sosialisasi Kawasan Keselamatan Operasi Penerbangan (KKOP) yang dilaksanakan di Desa Kemuning, Legok, Tangerang, Banten.
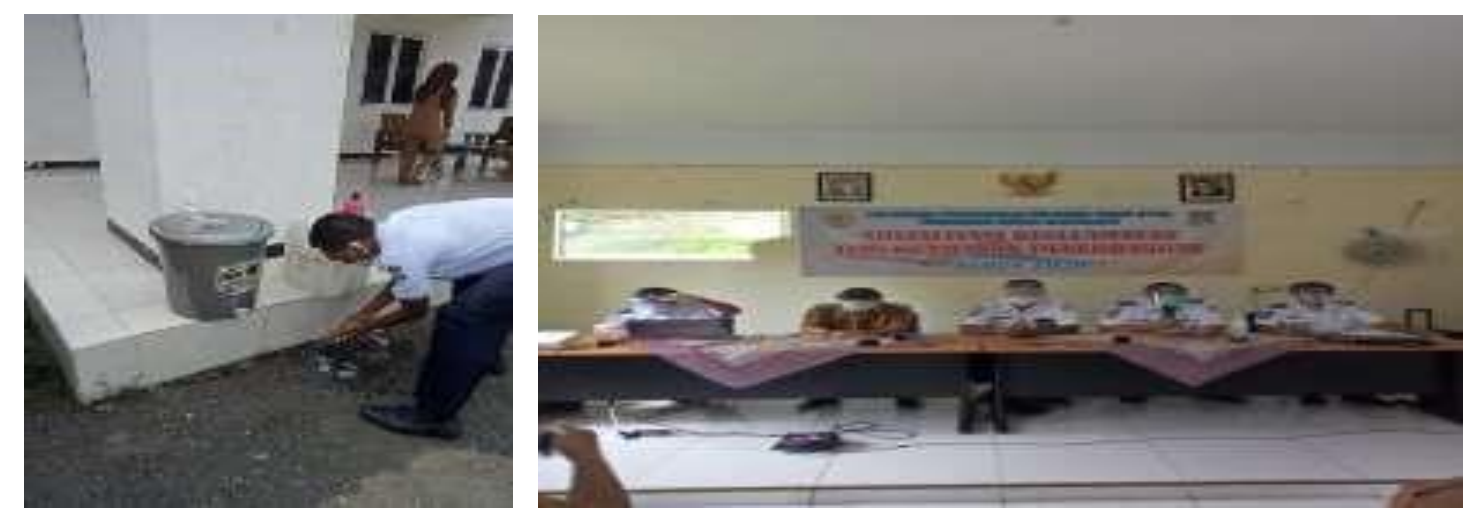

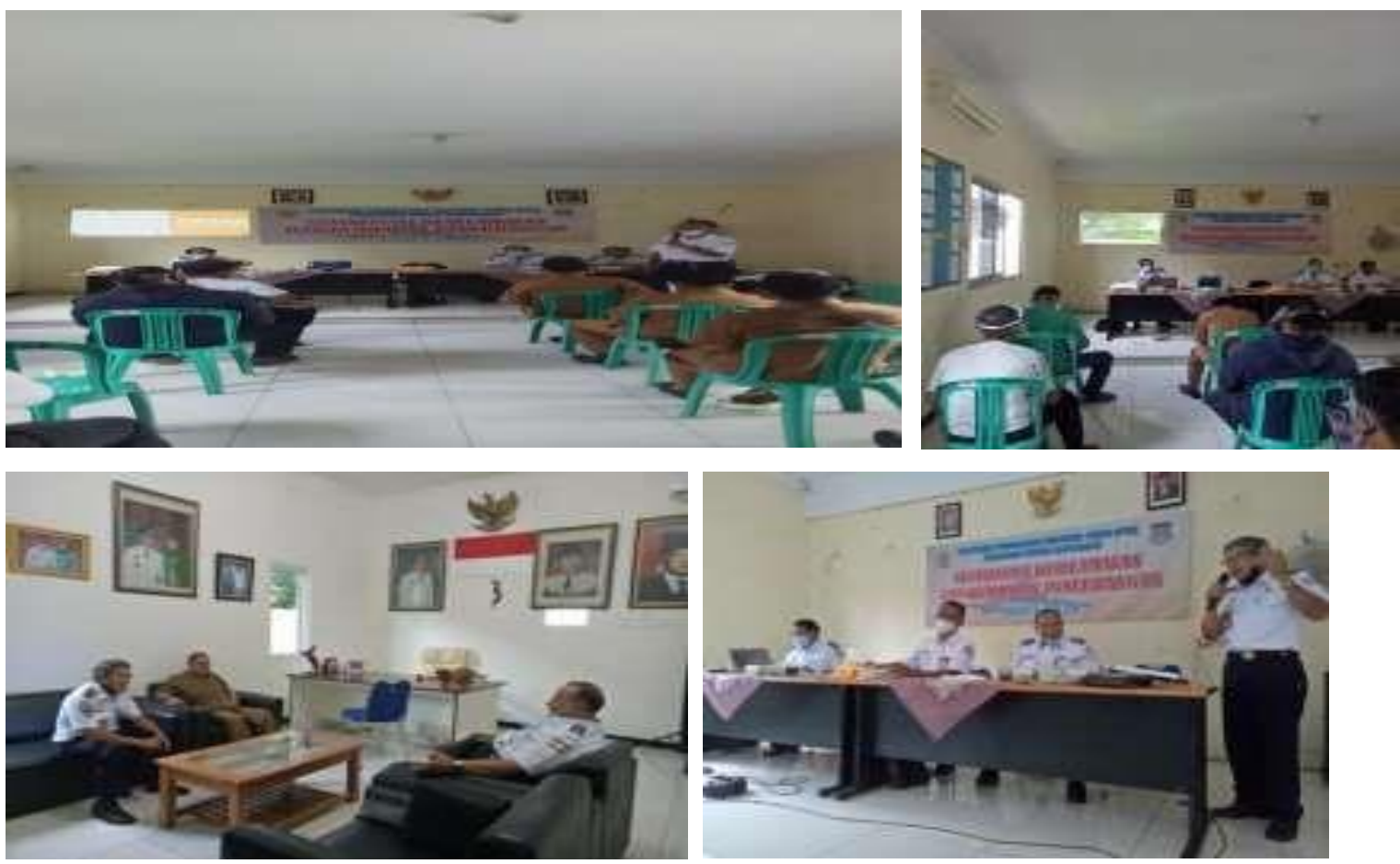

\section{Kesimpulan}

Kawasan keselamatan operasi penerbangan berfungsi sebagai pengatur dan pengendali ketinggian dari suatu bangunan atau benda tumbuh yang diperkirakan dapat menggangu keselamatan operasi penerbangan pesawat. Dan sebagai pengatur serta pengendali tata guna lahan di sekitar bandar udara untuk penyusunan tata ruang suatu wilayah. Ketentuan bangunan/benda tumbuh di KKOP adalah

a. Tidak menimbulkan gangguan terhadap isyarat-isyarat navigasi penerbangan atau komunikasi radio antar bandar udara dan pesawat udara;

b. Tidak menyulitkan penerbang membedakan lampu-lampu rambu udara dengan lampulampu lain;

c. Tidak menyebabkan kesilauan pada mata penerbang yang mempergunakan bandar udara;

d. Tidak melemahkan jarak pandang sekitar bandar udara;

e. Diperlukan rekomendasi dari Dirjeund terkait batas ketinggian rencana bangunan di KKOP.

Melalui kegiatan ini diharapkan masyarakat dapat memahami pentingnya menjaga keselamatan di Kawasan keselamatan operasi penerbangan serta memiliki kewaspadaan ketika beraktifitas di sekitar area bandar udara. Sebagai salah satu peran tridharma Perguruan tinggi perlu adanya pendekatan secara persuasip dan edukatif untuk terus memberi pemahaman akan pentingnya kesadara masyaraka demi menjamin keselamatan bersama. Sosialisasi dan pelatihan-pelatihan diharap akan mampu menjawab permasalahan terkait dengan kondisi kemasyaraakatan yang tradisional kearah modern dengan modal pelatihan yang akan membekali mereka menjadi lebih mandiri

Untuk membantu mengatasi kemungkinan adanya pelanggaran memasuki Kawasan parimeter, perlu memberi papan-papan peringatan pada daerah/bagian wilayah tertentu dan dalam diskusi pada saat sosialisasi hal ini semapat menjadi usulan salah satu tokoh masyarakat. 


\section{Penghargaan/Ucapan terima kasih}

Kegiatan Pengabdian Kepada Masyarakat tentang Kawasan Keselamatan Operasi Penerbangan (KKOP) yang dilaksanakan di Desa Kemuning, Legok, Tangerang, Banten ini didanai dari DIPA Politeknik Penerbangan Indonesia tahun anggaran 2020.

\section{Daftar Pustaka}

Andius Dasa Putra; Aleksander Purba. 2009. "Analisis Kawasan Keselamatan Operasi Penerbangan (Kkop) Bandar Udara Pekon Serai Di Kabupaten Lampung Barat.” Jurnal Sipil dan Perencanaan.

Airport Service Manual, (ICAO) doc. 9137 part 6. Control of Obstacle

Annex 14, International Civil Aviation Organization (ICAO), Vol, 1. Aerodromes

Peraturan Direktur Jenderal Perhubungan Udara nomor: 326 tahun 2019 tentang Standar

Teknis dan Operasional Peraturan Keselamatan Penerbangan Sipil-bagian 139

(Manual of Standard CASR-Part 139) Volume I Bandar Udara (aerodrome)

Peraturan Pemerintah no 70 Tahun 2001, tentang Kebandarudaraan

Peraturan Menteri Perhubungan nomor KM 11 Tahun 2010 tentang Tatanan kebandarudaraan nasional

Peraturan Menteri Perhubungan No 39 Tahun 2019 Tentang Tatanan Kebandarudaraan

Purwadio, HerHasuna, S, W Hastomo, E Sestri, and N Kalbuana. 2020. "Implementasi Association Rule $1 \&$ Frequent Pattern Growth Untuk Penentuan Sistem Rekomendasi Keputusan Pembelian.” Prosiding SeNTIK. https://jakstik.ac.id/ejournal3/index.php/sentik/article/view/295.

Kalbuana, N, and B Kurnianto. 2011. "Tinjauan Terhadap Motifasi Kaitannya Dengan Produktifitas Kerja Petugas Air Traffic Control Bandar Udara Soekarno ...." Langit Biru: Jurnal Ilmiah Aviasi. http://journal.ppicurug.ac.id/index.php/jurnal-langitbiru/article/view/307.

Kalbuana, N, B Kurnianto, R Saputro, and ... 2020. "The Effect of Audit Quality, Managerial Ownership, Institutional Ownership, and Intellectual Capital toward Earning Management on Transportation Corporations in ..." Solid State .... http://www.solidstatetechnology.us/index.php/JSST/article/view/8056.

Kurnianto, B, and N Kalbuana. 2011. "Analisis Sistem Keamanan Penerbangan Di Bandar Udara Sultan Syarif Kasim Ii-Pekanbaru." Langit Biru: Jurnal Ilmiah Aviasi. http://journal.ppicurug.ac.id/index.php/jurnal-langit-biru/article/view/322.

Lamtiar, S, Y Arnas, A A Rusdiyanto, and ... 2021. "Liquidity Effect, Profitability Leverage to Company Value: A Case Study Indonesia." European Journal of ... https://ejmcm.com/article_6290.html.

Lamtiar, S, N Desriyanto, R Robiansyah, and ... 2020. "Making Modeling Control System Of The Use Of Electrical Energy In A Flight Engineering Department Building Stpi CurugTangerang." International Journal of http://www.ijpsat.es/index.php/ijpsat/article/view/2393.

Mayhendra, Rizky Putra, and Linda Dwi Rohmadiani. 2016. "Pola Penggunaan Tanah Kawasan Pendekatan Dan Lepas Landas Bandara Internasional Juanda Surabaya.” Waktu: Jurnal Teknik UNIPA.

Purwadio, Heru, Putu Gde Ariastita, and Haryo Sulistyarso. 2017. "Pemintakan Kawasan Pengembangan Bangunan Tinggi Di Wilayah Surabaya Timur.” Jurnal Penataan Ruang. Purwanto, Eko Hadi et al. 2017. "Sistem Penunjang Keputusan Penerapan Kawasan Keamanan 
Operasi Penerbangan Bandara Buntukunik Di Kabupaten Tana Toraja." Prosiding Seminar Nasional Aplikasi Teknologi Informasi (SNATI).

Purwanto, Eko Hadi, and Ritzkal Ritzkal. 2018. "Penerapan Aplikasi Bantu KKOP Bandara Udara Buntukunik Di Kabupaten Tana Toraja.” KREA-TIF.

R. L., Viradhea Gita, S. Subiyanto, and A. Nugraha. 2014. "Tinjauan Peta Kawasan Keselamatan Operasi Penerbangan (Kkop) Bandara Ahmad Yani Semarang." Jurnal Geodesi Undip.

Standar Nasional Indonesia (SNI) 03-7112-2005 tentang Kawasan Keselamatan Operasi Penerbangan

Sugeng Budi Susilo, Yarianto, Siti Alimah, and June Mellawati. 2017. "Kajian Probabilitas Jatuhnya Pesawat Terbang Di Area Tapak Reaktor Daya Eksperimental (RDE) PUSPIPTEK Serpong.” Jurnal Pengembangan Energi Nuklir.

Susanti, E., A. Nugraha, and B. Yuwono. 2015. "Visualisasi 3d Peta Kawasan Keselamatan Operasi Penerbangan (Kkop) Bandara Ngurah Rai Bali.” Jurnal Geodesi Undip.

Undang-Undang No. 1 Tahun 2009 tentang Penerbangan, Kementerian Perhubungan

Winaya, Ida Bagus Gde, and Lita Tyesta A.L.W. 2016. "Pengaturan Kawasan Keselamatan Operasi Penerbangan: Studi Tentang Pelaksanaan Kewenangan Pemerintah Daerah Dalam Mengendalikan Pembangunan Dan Benda Tumbuh Di Kawasan Keselamatan Operasi Penerbangan Bandar Udara Ahmad Yani Semarang." LAW REFORM.

Zahra, Dimita Brilian, Ervina Ahyudanari, and Istiar Istiar. 2017. "Evaluasi Ketersediaan Ruang Udara Dalam Kaitannya Dengan Keselamatan Operasional Penerbangan Di Bandara Abdul Rachman Saleh.” Jurnal Teknik ITS 